\section{Comment on: mean platelet volume in patients with retinal artery occlusion}

\author{
Comentário sobre: volume médio de plaquetas em \\ pacientes com oclusão da artéria da retina
}

Dear Editor:

We read with great interest the article "Mean platelet volume in patients with retinal artery occlusion" by Şahin et al. ${ }^{(1)}$ published in your journal. In that very interesting, well-designed, and well-presented study, Şahin and coworkers found that mean platelet volume (MPV) values were significantly higher in the patient group than in the control group; they also showed that MPV was an independent predictor of retinal artery occlusion (RAO).

$\mathrm{RAO}$ is a rare cause of irreversible visual impairment seen particularly in older age groups and is caused by thrombotic and/or embolic events ${ }^{(1)}$. Changes in platelet activation play an important role in the pathogenesis of thromboembolic and/or inflammatory diseases. Platelet function plays a key role in the control of inflammatory response and thromboembolic disorders while also undergoing changes secondary to this process. MPV has a meaningful place in the evaluation of indicators of the size and activity of platelets ${ }^{(1,2)}$. Parameters, such as red cell distribution width (RDW) and neutrophil to lymphocyte ratio (NLR) of the underlying hemogram test, are important in characterizing thromboembolic disorders. Studies have shown that RDW and/or NLR values were higher in patients with retinal vein occlusion ${ }^{(3)}$ and coronary artery occlusion ${ }^{(4)}$ than in control patients.

MPV is a readily measurable laboratory marker used to evaluate systemic inflammation and/or thromboembolic disorders. On the other hand, the use of MPV is limited by several factors, including hypertension, diabetes mellitus, metabolic syndrome, obesity, hyperlipidemia, renal/ hepatic dysfunction, thyroid abnormalities, hematological disorders, blood transfusion, malignancies, cardiac or heart valve diseases, asthma, chronic obstructive pulmonary disease, peripheral/cerebral vascular disease, anemia, B12 and folic acid deficiency, history of smoking and alcohol consumption, and the use of any medication related to inflammatory/thromboembolic status of patients; thus, measurement of the MPV can be important in these situations ${ }^{(1,5)}$. Nevertheless, it is very significant that the MPV increased over time in the EDTA-anticoagulated samples. Because their study was retrospectively designed, the authors cannot precisely describe how much time elapsed before measuring the MPV values, but we wish to point out that delaying blood sample testing may lead to changes in results in MPV measurements ${ }^{(5)}$.

In conclusion, this study led us to consider that MPV may be assessed as a marker to identify patients with thromboembolic disorders. We believe that MPV and the other markers, NLR and RDW, should be evaluated together in future multi-directional prospective studies in patients with RAO.

\section{Emre Pehlivan 1, Ali Ugur Uslu², Salih Uzun ${ }^{3}$ Yahya Sekin ${ }^{2}$}

Submitted for publication: May 12, 2016

Accepted for publication: May 20, 2016

Department of Ophthalmology, Eskisehir Military Hospital, Eskisehir, Turkey.

2 Department of Internal Medicine, Eskisehir Military Hospital, Eskisehir, Turkey.

Department of Ophthalmology, Etimesgut Military Hospital, Ankara, Turkey.

Funding: No specific financial support was available for this study.

Disclosure of potential conflicts of interest: None of the authors have any potential conflict of interest to disclose.

Corresponding author: Ali Ugur Uslu. Department of Internal Medicine. Eskisehir Military Hospital Visnelik Mah., Atatürk Cd. 26020 - Akarbasi, Eskisehir - Turkey - E-mail: drauuslu@gmail.com

\section{REFERENCES}

1. Şahin M, Şahin A, Yüksel H, Türkcü FM, Yıldırım A. Mean platelet volume in patients with retinal artery occlusion. Arq Bras Oftalmol. 2016;79(1):12-4

2. Uslu AU, Aydin B, Balta S, Yonem O, Uncu T, Seven D. The effect of standard therapy on mean platelet volume in patients with chronic hepatitis C. Prz Gastroenterol. 2016; doi:10.5114/pg.2016.57942.

3. Dursun A, Ozturk S, Yucel H, Ozec AV, Dursun FG, Toker Ml, et al. Association of neutrophil/ lymphocyte ratio and retinal vein occlusion. Eur J Ophthalmol. 2015;25(4):343-6.

4. Baysal E, Çetin M, Yaylak B, Altntaş B, Altndağ R, Adyaman \$̧, et al. Roles of the red cell distribution width and neutrophil/lymphocyte ratio in predicting thrombolysis failure in patients with an ST-segment elevation myocardial infarction. Blood Coagul Fibrinolysis. 2015;26(3):274-8.

5. Balta S, Demir M, Demirkol S, Ozturk C, CelikT. Mean platelet volume in patients with varicocele. Andrologia. 2015;47(4):365-6.

\section{Response: comment on: mean platelet volume in patients with retinal artery occlusion}

\author{
Resposta do comentário sobre: \\ volume médio de plaquetas em pacientes com \\ oclusão da artéria da retina
}

\section{Dear Editor:}

We read with interest the comments on our article ${ }^{(1)}$ regarding the "Mean platelet volume (MPV) in patients with retinal artery occlusion." We thank the authors for their interest in our study. The authors commented that the MPV increased over time in the EDTA-anticoagulated samples. Therefore, the time after sampling is important when evaluating MPV.

We agree with the authors that the elongated time after blood sampling may alter the MPV values. Lancé et al. reported that the optimal hemogram time to analysis is $\leq 120 \mathrm{~min}$ after venipuncture sampling ${ }^{(2)}$. Moreover, in our hospital the hemogram tests were performed within $1 \mathrm{~h}$ after sampling. The blood samples were taken and immediately sent to the laboratory for routine hemogram analyses. Although ours was a retrospective study, we mentioned in the Materials and Methods section that blood samples were analyzed within $1 \mathrm{~h}$ after sampling in our laboratory routinely. In conclusion, we thank the authors for their comments, and hope that our explanation will help readers assess our study results in the proper context.

\section{Muhammed Şahin', Alparslan Şahin", Harun Yüksel', Fatih Mehmet Türkcü', Adnan Yıldırım ${ }^{1}$}

Departments of Ophthalmology, School of Medicine, Dicle University, Diyarbakir, Turkey. Corresponding author: Muhammed Şahin. Department of Ophthalmology - School of Medicine Dicle University - Diyarbakir, Turkey

\section{REFERENCES}

1. Şahin M, Şahin A, Yüksel H, Türkcü FM, Yıldırım A. Mean platelet volume in patients with retinal artery occlusion. Arq Bras Oftalmol. 2016;79(1):12-4

2. Lancé MD, van Oerle R, Henskens YM, Marcus MA. Do we need time adjusted mean platelet volume measurements? Lab Hematol. 2010;16(3):28-31. 